\title{
Territorial Integrity Treaties and Armed Conflict over Territory
}

\author{
Paul R. Hensel \\ Department of Political Science \\ University of North Texas \\ 1155 Union Circle \#305340 \\ Denton, TX 76203-5017 \\ phensel@unt.edu \\ Michael E. Allison \\ Department of Political Science \\ University of Scranton \\ 409 O'Hara Hall \\ Scranton, PA 18510-4648 \\ allisonm3@scranton.edu
Ahmed Khanani
Indiana University
1100 E. 7th St.
Bloomington, IN 47405-7110
akhanani@indiana.edu \\ Department of Political Science
}

An earlier version of this paper was presented at the 2006 Shambaugh Conference "Building Synergies: Institutions and Cooperation in World Politics," University of Iowa, 13 October 2006. The authors wish to thank the Shambaugh Conference participants and the journal's anonymous reviewers for their valuable comments and suggestions, while taking full blame for all errors and interpretations herein. 


\title{
Territorial Integrity Treaties and Armed Conflict over Territory
}

\begin{abstract}
We reconceptualize a territorial integrity norm that has been discussed in recent research, distinguishing between general guarantees of territorial integrity and proscriptions of the forcible acquisition of territory, and we measure the strength of this norm using treaties. Over the past two centuries, the general territorial integrity norm has reduced territorial conflict, but treaties proscribing only violent gains are associated with increased conflict. The norm's strongest effects stem from pressure by other states that have accepted the norm rather than from direct effects of treaties, and territorial integrity treaties have typically followed rather than preceded a reduction in territorial conflict.
\end{abstract}

Short Title: Territorial Integrity Treaties

\section{Territorial Integrity Treaties and Armed Conflict over Territory}

In a recent article, Zacher (2001) discusses a territorial integrity norm that appears to have developed in the twentieth century. He describes this norm as rejecting attempts to change the territorial status quo through the threat or use of force. Zacher's evidence suggests that once the norm became widespread, there were few cases of successful violent territorial aggrandizement in the first three decades since World War II, and none since the mid-1970s.

Although Zacher's evidence seems persuasive, the underlying norm appears to reject more than just successful challenges to the territorial status quo; any attempt to acquire territory forcibly would seem to violate the norm. Furthermore, many treaties with territorial integrity provisions offer blanket guarantees of signatories' territorial integrity, not just condemnation of the forcible acquisition of territory. We thus reconceptualize this norm to distinguish between general guarantees of territorial integrity and the rejection of force for acquiring territory.

We measure the evolving strength of the territorial integrity norm through treaty commitments, and then examine the impact of this norm on several forms of territorial conflict. Our results suggest that the norm has had a mixed impact, with general territorial integrity 
obligations reducing territorial conflict but violent obligations actually associated with increased conflict. These effects are due primarily to the level of global acceptance of territorial integrity obligations, rather than potential adversaries' shared treaty obligations. Furthermore, relatively few territorial integrity treaties have had a significant effect on territorial conflict between their signatories, and most such treaties were signed in contexts with little territorial conflict. We conclude by discussing possible directions for future research in this area.

\section{Studying Territorial Integrity Norms}

Our conceptualization of international norms follows Krasner's (1982: 186) definition as "standards of behavior defined in terms of rights and obligations." Like Florini (1996: 364-365) and Finnemore and Sikkink (1998), we emphasize "the sense of 'ought"' and the notion of legitimate behavior, which distinguish norms from observable behavioral regularities. A systematic analysis of a given norm must thus indicate which general class of behavior is addressed, which specific behaviors within this general class are considered legitimate, and why these behaviors are considered legitimate (rather than simply being observed empirically).

It is also important to be able to measure the strength of the norm over time. Finnemore and Sikkink (1998: 895-905) describe the strength of norms as evolving through three stages. In the norm emergence stage, norm entrepreneurs (typically private citizens, often with organizational platforms to help spread their message) attempt to convince state leaders to follow their desired norm. In the norm cascade stage, the "norm leaders" -- states that have accepted the norm -- attempt to socialize other states to accept the norm and become "norm followers." Some budding norms may fail in either the emergence or cascade stages, if the entrepreneurs or norm leaders are unable to convince enough states to follow them. Others reach the norm 
internalization stage, by the end of which "norms acquire a taken-for-granted quality and are no longer a matter of broad public debate" (Finnemore and Sikkink 1998: 895).

Working from insights such as these, the scientific study of world politics has begun to focus on norms, offering systematic measurement and evaluation of norms pertaining to decolonization (Goertz and Diehl 1992), alliance commitments (Kegley and Raymond 1990), and peaceful dispute settlement (e.g., Dixon 1993; Mitchell 2002), among others. Zacher (2001) has extended this list by suggesting that the past two centuries have seen the development of a norm of territorial integrity. We now examine Zacher's characterization of this norm, before offering our own refinement of what the norm includes and how to measure it.

\section{Zacher's Territorial Integrity Norm}

According to Zacher (2001: 215), the territorial integrity norm refers to "the growing respect for the proscription that force should not be used to alter interstate boundaries." Zacher (2001: 216-221) describes this norm as developing out of the rise of nationalism in the nineteenth century. Before that time, territories frequently changed hands with the expansion or contraction of states and empires. As nationalism developed, though, a norm began to take shape that opposed transferring one state's people to rule by another state. Zacher (2001: 238-244) describes the spread of the norm as being driven by Western democracies and reflecting such factors as the association of territorial revisionism with major wars, liberalism's emphasis on national self-determination, and the changing costs and benefits of territorial aggrandizement.

Zacher (2001: 236) writes that the emergence phase of the norm began with the postWorld War I peace settlement. The norm was reflected in one of Woodrow Wilson's Fourteen Points: "specific covenants for the purpose of affording mutual guarantees of political 
independence and territorial integrity to great and small states alike," and was encapsulated in Article 10 of the League of Nations Covenant: "The members of the League undertake to respect and preserve as against external aggression the territorial integrity and existing political independence of all Members of the League." After World War I, Zacher (2001: 220-221) notes, the norm was applied unevenly; there were numerous transfers of territory from the defeated Central Powers, and the norm's supporters did little to oppose interwar territorial conquests. By the end of World War II, though, the major democratic powers followed the norm much more closely, generally rejecting territorial gains at the expense of the defeated Axis.

Zacher (2001: 236-237) describes the acceptance (or cascade) stage of the norm as beginning with the adoption of the UN Charter: "It was not until the 1960s and early 1970s that broad and strong backing for the norm became palpable." Article 2(4) of the Charter explicitly prohibits the threat or use of force against the territorial integrity of any state, and similar principles were included in such documents as the OAS and OAU charters and the Helsinki Final Act (Zacher 2001: 221-223, 237). Finally, Zacher (2001: 237) describes the institutionalization (or internalization) stage of the norm as running from 1976 to the present, when third parties have acted to ensure that force does not lead to the successful acquisition of territory. ${ }^{1}$

In order to determine the impact of the norm, Zacher (2001: 223-224) examines a list of 133 territorial wars between 1648-2000. Approximately $80 \%$ of the wars before 1945 led to the redistribution of territory, as compared to only $30 \%$ between $1946-2000$, and the number of territorial redistributions per year also dropped substantially. Importantly, Zacher (2001: 237) also reports that during the institutionalization stage of the norm's development (since 1975) there has not been a single major case of successful territorial aggrandizement. 
Zacher's evidence appears persuasive initially, but his caveat (2001: 224) that "the criteria for the inclusion of wars differs for the pre- and post-1945 years, and there is no claim of statistical significance" raises doubts. It would be desirable to assess the impact of this norm more systematically, employing more rigorous coding rules and standards of significance. We also have several further concerns with Zacher's approach that must be addressed before we can be confident in the impact of this norm. We are concerned with the identification of a single norm, when analysis of the relevant treaties suggests two distinct norms related to territorial integrity. We also suggest that closer attention needs to be paid to the behavior that is studied to evaluate the impact of the norm. While successful territorial aggrandizement should indeed count as evidence against a territorial integrity norm, we believe that the outbreak of armed conflict over territory (even if unsuccessful) should count as a violation of such a norm. ${ }^{2}$

\section{Reconceptualizing Territorial Integrity Norms}

We submit that instead of a single territorial integrity norm as described by Zacher, two distinct territorial integrity norms have been featured in multilateral treaties and institutions. Some treaties have specifically proscribed the acquisition of territory through the threat or use of military force; this was Zacher's focus. Others encapsulate the notion of territorial integrity more generally, not limited to the rejection of forcible changes in territory. Because these latter treaties call explicitly for respect for all borders rather than only rejecting violent acquisition of

\footnotetext{
${ }^{1}$ For example, following the Iraqi invasion of Kuwait in 1991, the United Nations authorized a coalition of states to intervene and prevent a successful Iraqi acquisition of territory.

${ }^{2}$ While Zacher finds that force has been much less successful at acquiring territory since 1945, he identifies forty territorial conflicts during this period, and Huth and Allee (2002) and the ICOW project (Hensel 2001) identify over 100 territorial claims during this time. The fact that so many states seek territorial revisions seems to cast doubt on the effectiveness of the norm.
} 
territory, they appear to be a broader and more comprehensive norm against territorial change, and they may be expected to have different consequences for international behavior.

The first multilateral treaty to contain an explicit territorial integrity obligation, the League of Nations Covenant, proscribed the violent acquisition of territory in Article 10. Most other early efforts to encapsulate territorial integrity provisions in multilateral treaties followed similar approaches; details of each treaty are provided in this paper's Internet Appendix. ${ }^{3}$ Such treaties include the Saavedra Lamas Pact and Montevideo Convention on Rights and Duties of States in 1930s Latin America, the UN Charter and OAS Charter after World War II, and the ECOWAS Protocol on Non-Aggression and SADC Protocol on Politics, Defense, and Security Cooperation in contemporary Africa. ${ }^{4}$ In each case, the emphasis was on preventing war over territory, while still allowing peaceful transfers of territory by mutual agreement.

More recently, though, there has been a trend toward more general respect for territorial integrity, with no explicit limitation to the proscription of violent acquisition of territory. The first such effort was the Locarno Pact (Pact of Mutual Guarantee) in interwar Europe, which sought to prevent Germany from challenging its western borders with France and Belgium. In Article 1 of this pact, the signatory states guaranteed "the maintenance of the territorial status quo resulting from the frontiers between Germany and Belgium and between Germany and

${ }^{3}$ This appendix is available at <http://www.paulhensel.org/Research/cmps09app.pdf>.

${ }^{4}$ This list is based on the Multilateral Treaties of Pacific Settlement data set, which is limited to treaties and institutions that contain at least five member states. Zacher (2001) lists several other treaties or documents that we do not include, because we do not believe that they qualify. For example, the Kellogg-Briand Pact and Pact of the League of Arab States both renounce war and call for the peaceful settlement of disputes, but neither specifically mentions territorial integrity , and the Arab League document explicitly rejects applying the League's obligatory peaceful settlement mechanism to territorial questions between members. Zacher (2001: 221) also describes decolonization as an example of this norm, listing several UN documents because they called for the independence of entire colonies rather than the self-determination of each individual ethnic or tribal group. Yet this is not fully consistent with the territorial integrity 
France, and the inviolability of the said frontiers as fixed by or in pursuance of the Treaty of Peace signed at Versailles on June 28, 1919." German demands for territory through the threat or use of force were banned, but so were peaceful demands for territorial revision; the pact was intended to prevent any challenge to the Versailles settlement in Western Europe. ${ }^{5}$

The Locarno Pact was the only general territorial integrity obligation for more than three decades, until the decolonization of Africa. The borders between European colonies in Africa were often unnatural, cutting across traditional ethnic or linguistic groups and producing illfitting multiethnic colonial entities (Herbst 1989). As a result, leaders in the region chose to avoid uncertainty and conflict by preserving their existing colonial boundaries; it was feared that allowing challenges to any African borders on the grounds of illegitimacy could lead to the emergence of challenges against virtually every African border for the same reason. (Malanczuk 1997: 162; Ratner 1996: 595-596; Zacher 2001: 221-223) ${ }^{6}$ The OAU Charter thus contained explicit support for territorial integrity in this general sense. Article 2 listed one of the purposes of the organization as "To defend [the African states'] sovereignty, their territorial integrity, and independence," while Article 3 elaborated by declaring adherence to the principle of "Respect for

norm that he describes, which concerns the rejection of territorial acquisition by force. ${ }^{5}$ Bell (1997: 36-37) notes that the Locarno Pact had great symbolic value in "confirming the territorial settlement in western Europe on a freely negotiated basis," and Gilbert (1984: 221222) notes that "the frontiers between Germany, France, and Belgium -- and the permanent demilitarization of the Rhineland -- were now recognized as final." The importance of this general rejection of territorial change becomes clear when compared to other agreements signed at Locarno; Germany refused to accept its new borders with Poland and Czechoslovakia, and would only agree that those borders could not be challenged militarily.

${ }^{6}$ A number of African leaders argued in favor of this territorial integrity provision at the OAU's 1964 Cairo summit. For example, President Tsiranana of Madagascar declared that "It is no longer possible, nor desirable, to modify the boundaries of Nations, on the pretext of racial, religious, or linguistic criteria." Despite objections from Somalia and Morocco, the resolution passed easily after just forty minutes of discussion, and the OAU adhered rigidly to the principle of the territorial status quo in subsequent years. (Chime 1969: 67; Touval 1972: 86-90) 
the sovereignty and territorial integrity of each State and for its inalienable right to independent existence." Similar provisions subsequently appeared in at least eleven more treaties. ${ }^{7}$

This distinction between violent and general territorial integrity obligations appears to be an important one. Most early efforts accepted the possibility of peaceful territorial change while opposing the acquisition of territory through violent or coercive means. However, in cases such as Locarno and the OAU even peaceful change was seen as a serious threat, and the existing borders (whether created through Versailles or through colonization) were not to be challenged through either peaceful or military means. If the explicit content of a norm is to be taken as a guide to the norm's intended effects, it appears reasonable to offer the following hypotheses:

Hypothesis 1: Militarized challenges to territory should be less likely when there is a stronger global territorial integrity norm (including either violent or general territorial integrity provisions).

Hypothesis 1a: Violent transfers of territory should be less likely when there is a stronger global territorial integrity norm (including either violent or general territorial integrity provisions).

Hypothesis 1b: Peaceful transfers of territory should be less likely when there is a stronger global general territorial integrity norm; violent territorial integrity provisions should have little systematic impact on peaceful transfers.

${ }^{7}$ The Helsinki Final Act calls for territorial integrity and the inviolability of frontiers, in line with Soviet desires for the binding recognition of the territorial changes that followed World War II; this appears to be a general territorial integrity obligation. The Act opens with a declaration that frontiers could be changed peacefully with the agreement of the parties, though, reflecting West Germany's interest in a peaceful reunification of Germany and general Western unwillingness to recognize the East European borders as irrevocable; this qualifies the document as a violent territorial integrity obligation. (Russell 1976: 249-253; Bowker and Williams 1985) 
While the first set of hypotheses will allow a more rigorous empirical analysis of the territorial integrity norm, aggregated analyses of global patterns may miss important effects. One reason is the classic aggregation problem; such analyses are unable to determine whether the states that have accepted territorial integrity obligations are the ones that engage in any observed territorial conflict. It would also be desirable to control for the impact of additional variables that are believed to influence conflict propensity. If most states that have accepted territorial integrity obligations would not be expected to fight each other even without such obligations, it would be misleading to attribute their avoidance of armed conflict to the norm; there may be a selection effect with respect to which states choose to accept territorial integrity obligations.

This discussion suggests that the impact of territorial integrity norms can be tested most appropriately using the dyadic rather than global level of analysis, examining the treaty obligations of specific pairs of potential adversaries while controlling for the impact of other factors that appear likely to affect their conflict behavior. The norm's impact should be observed best with such analyses, insofar as the treaty obligations should be the main avenue for the norm's effects; most observers would expect the effects of the norm to be strongest for states that have accepted its obligations in treaty form. This leads to the following hypothesis:

Hypothesis 2: Militarized challenges to territory should be less likely, ceteris paribus, between states that share more territorial integrity treaty obligations (including either violent or general territorial integrity provisions). 
While Hypothesis 2 examines what might be considered a direct effect of treaty

obligations on the states that have signed and ratified a treaty, it is also possible that the norm has an effect on non-signatory states. If most state accept the norm, then their combined pressure may be sufficient to influence the behavior of non-signatory states with respect to the content of the norm. ${ }^{8}$ A state that does not formally accept any territorial integrity obligations could still refrain from challenging the territorial status quo because of the diplomatic or other pressure of other states that have accepted such obligations -- much like Mitchell (2002) has argued that democratic norms can influence the behavior of non-democratic states when enough of the interstate system is democratic. We introduce a final hypothesis to address this possibility:

Hypothesis 3: Militarized challenges to territory should be less likely, ceteris paribus, when there is a stronger global territorial integrity norm (including either violent or general territorial integrity provisions) -- even for states that have not accepted the norm in the form of explicit treaty obligations.

\section{Research Design}

These hypotheses will be tested using two approaches. First, we will undertake an analysis of global patterns of territorial conflict since 1816. This approach, similar to Zacher's (2001) preliminary evaluation of the territorial integrity norm, will allow us to determine how much impact both violent and general territorial integrity obligations have had on conflict over

${ }^{8}$ This is consistent with Zacher (2001), who considers the 1991 Gulf War to be a successful example of the norm. While Iraq violated the norm by annexing Kuwait, the international effort to liberate Kuwait demonstrates the impact of a system where the norm was widely accepted. 
territory. We will supplement this with a more detailed dyadic analysis, which will allow us to examine the impact of territorial integrity norms while controlling for other relevant factors.

\section{Global Impact of Territorial Integrity Norms}

Our analyses examine territorial conflict from 1816-2001 (the time span covered by the needed data sets). The purpose is to determine whether the increasing strength of the territorial integrity norm over time has been associated with a reduction in territorial conflict. This approach is similar to that of Zacher (2001), who examined the number of territorial conflicts and the proportion of these conflicts that led to the redistribution of territory.

We seek to improve on Zacher's analyses in several ways. First, we offer multiple measures of the changing strength of territorial integrity norms over time, which we believe will allow a more accurate assessment of the norms' impact. We also examine this impact using multiple indicators of territorial conflict, ranging from low-level armed conflict over territory to the violent transfer of territory between nation-states. Finally, whereas Zacher (2001: 224) explicitly noted that he was making no claim about the statistical significance of his results, we seek to use statistical techniques to gain a more detailed understanding of the norm's impact.

\section{Measuring Territorial Integrity Norms}

Zacher measured the global strength of the territorial integrity norm by identifying historical eras that correspond to the stages of norm development, primarily by reference to international treaties and documents that seemed to embody this norm. We believe that a more accurate measurement can be made by reference to the treaties' signatories. That is, rather than identifying global periods that seem to fit various stages of norm development, we measure the 
average territorial integrity obligations that each state has accepted in a given year. When the average state has signed and ratified more treaties with territorial integrity obligations, we believe that the norm is stronger, as states have been willing to accept more obligations.

This approach identifies variation in the norm's strength within each of the various stages of norm development that Zacher identified, and appears to offer a more precise measure of the strength of the norm at any given point in time. For example, Zacher identifies the emergence phase of the norm as beginning with the League of Nations Charter and running through the end of World War II. Yet the norm likely changed in strength over this time, as some states took on additional territorial integrity obligations, others abandoned previous obligations, and other states became independent without taking on any such obligations. Measuring the strength of the norm by specific treaty obligations allows us to determine how strong the norm was at any given point in time, based on the average obligations that each state had been willing to accept at that time.

[Figure 1 about here]

We have already described the differences between violent and general territorial integrity obligations, and presented a list of treaties encapsulating each type of obligation. Figure 1 presents the average number of territorial integrity obligations for each state in the international system, both overall and for each stage in the territorial integrity norm as described by Zacher. There were no qualifying treaties of either type before 1919. During what Zacher describes as the norm's emergence stage (1919-1945), each state has an average of 1.0 violent territorial integrity obligations per year, reflecting membership in the League of Nations for most states as well as signature of several regional treaties; there is also an average of 0.03 general obligations, reflecting the Locarno Pact. In the norm cascade stage (1946-1975), these figures rise to 1.47 violent obligations and 0.36 general obligations, and the total commitments rises 
from 1.03 to 1.83 per year. Finally, in the norm internalization stage (1976-2001), violent obligations increase slightly to 1.71 and general obligations increase substantially to 1.32 , for a total of 3.04 obligations per year. These obligations are consistent with Zacher's characterization of the norm's phases, with the added benefit of capturing variation in the strength of the norm within each phase as new states join existing treaties or new treaties are signed. ${ }^{9}$

While treaty commitments offer a better way to measure the strength of territorial integrity norms than categorizing several decades of history as corresponding to a specific stage of the norm, this approach does have several limitations. First, signing a treaty that includes a territorial integrity obligation implies some level of support for the territorial integrity norm, or at least some willingness to behave consistently with the norm, but there are also other reasons that a state might sign such a treaty. Particularly for large multipurpose treaties like the charters of the League of Nations or United Nations, a state may see a number of benefits to signing the treaty while not accepting every single element of the treaty or charter.

Second, it is possible to accept the norm without signing any treaties that embody it; indeed, if the norm were widely accepted throughout the world, it would not need to be encapsulated in formal treaties. Furthermore, a state's commitment to the norm may strengthen over time after signing a treaty, as the state's leaders and citizens internalize the norm.

\footnotetext{
${ }^{9}$ One reviewer suggested that we could learn more about the norm from the proportion of relevant treaties that include explicit territorial integrity provisions. The "relevant" category is difficult to determine, though; our 23 cases range from regional or global organizations to treaties that are not associated with any organization. One possible starting point is the COW Intergovernmental Organizations data set, which includes 302 IGOs with at least five members (the threshold for the MTOPS data used in this paper) in 2000 and just 39 in 1915. The total number of IGOs has increased dramatically, but it is not clear that this helps us understand the impact of the norm. Instead, if the norm is to constrain a state's behavior, this constraint seems more likely to be reflected by a larger absolute number of treaty commitments with explicit territorial integrity provisions than by the number of treaty commitments that do not include such provisions (which is the main additional information that would be provided by a proportion).
} 
Conversely, a state's commitment to the norm may weaken after signing a treaty, as the state's leaders find that the norm conflicts with their interests or as they observe other states violating the norm (although this weakening would be picked up by our measure if the weakening commitment led the state to withdraw from the treaty).

With these caveats in mind, though, we submit that treaty commitments offer a reasonable measure of states' commitments to the territorial integrity norm, and that this measure is more accurate than delimiting historical periods when the norm was believed to have been stronger. We believe that (ceteris paribus) when states accept treaties that include explicit territorial integrity obligations, they typically do so because they have some level of support for the norm, and furthermore states that have signed and ratified more such treaties generally have more support for the norm than states that have less. Following Zacher, we also believe that such treaties do a reasonable job of capturing the development of the norm over time; Zacher dates the first explicit phase of the norm's development from the signing of the League of Nations Charter, and his discussion of the strengthening of the norm over time is based heavily on the signing of subsequent treaties. While there may have been states that accepted this norm without signing any relevant treaties, and other states that signed such treaties without accepting the norm, we believe that treaty obligations offer a better measure of the strength of the norm than any alternative. In any case, to ensure the fairest possible test of this norm's impact, our analyses will use Zacher's historical periods as an alternative measure of the norm's strength.

\section{Dependent Variables}

In testing the impact of the territorial integrity norm, it is important to specify exactly which types of behavior would constitute a violation of the norm. Zacher focused on successful 
territorial aggrandizement by force, which he measured by major territorial aggressions that led to the redistribution of territory. We focus on multiple forms of conflict over territory, arguing that different treaty obligations specify different behaviors that are proscribed.

First, we are interested in the outbreak of armed conflict over territory. Unlike Zacher, we consider the threat or use of military force to be in opposition to the territorial integrity norm, because it represents the type of behavior that the norm seeks to prevent; we believe that a successful norm should prevent attempts to conquer or otherwise acquire territory by force, as well as preventing the success of such attempts when they are made. We measure this using version 3.02 of the Correlates of War (COW) militarized interstate dispute data set (Ghosn et al. 2004), using the status quo revision variables to determine whether at least one of the disputants was attempting to modify the territorial status quo. One potential objection is that many militarized disputes only include isolated threats that never escalate to more dangerous levels, and thus would not qualify as what Zacher (2001) called "territorial wars" or "major military conflicts." Our main analyses thus focus only on militarized disputes over territorial issues that led to at least one battlefield fatality, although we supplement these analyses with robustness checks using all disputes over territory as well as only those that produced at least 100 fatalities.

Following Zacher, we also recognize that the success of efforts to acquire territory is important. We thus include additional analyses examining the transfer of territory, as measured by the COW Territorial Change data set (Goertz and Diehl 1992). We also distinguish between territorial changes that occur through peaceful means and those that occur through organized violence. Both violent and general territorial integrity obligations seek to prevent the violent transfer of territory, but violent obligations appear to allow the peaceful transfer of territory, making this an important distinction for analysis. 


\section{Dyadic Impact of Territorial Integrity Norms}

We supplement the analysis of global patterns with an analysis that considers all possible dyadic adversaries, or the different pairs of states that might become involved in territorial conflict. These dyadic analyses require a population of cases that might reasonably be expected to become involved in territorial conflict. Rather than include hundreds of dyads such as Bolivia and Bangladesh that have no real prospect of conflict over any issue, much less over territory, we focus on two types of dyads: those composed of two states located in the same geographic region, and those composed of one major power and one other state in the international system. Our data set includes a dyad-year-level observation for each year that both states were independent nation-states, as identified by the COW interstate system membership list. ${ }^{10}$

Our dyad-year-level analyses focus on only one of the dependent variables from the global analysis, fatal militarized conflict over territorial issues. The primary independent variables of interest are largely the same as in the global analyses: the historical development of the territorial integrity norm as described by Zacher, and the global average of both general and violent territorial integrity obligations in a given year. These are supplemented by the number of territorial integrity obligations shared by the states in the dyad, in order to determine whether the dyad's specific treaty commitments have a statistically discernible impact on conflict behavior.

\section{Control Variables}

${ }^{10} \mathrm{We}$ also ran the analyses with the subset of contiguous dyads. None of the results for our key independent variables changed, increasing our confidence that the results are not being driven by including non-contiguous dyads in each region or dyads including distant major powers. 
In order to avoid exaggerating the impact of the norm, these analyses control for the impact of other factors. A variety of research suggests that armed conflict is less likely between two political democracies; joint democracy is measured with the Polity 4 data set, and indicates whether or not both claimants received scores of six or greater on the Polity index of institutionalized democracy. Our second control variable accounts for relative capabilities; if one state is substantially stronger than its opponent, then we might expect conflict to be much less likely than would be the case between two relatively even adversaries, drawing from a variety of research indicating that relative parity is much more conflictual than preponderance by one side. Relative capabilities are measured using the Composite Index of National Capabilities (CINC) score from version 3.01 of the COW National Material Capabilities data set (Singer 1988), taking the stronger side's CINC score as a percentage of the dyadic total. We also control for conflict history, using both the number of "peace years" since the most recent fatal territorial dispute in the dyads and three splines, as suggested by Beck, Katz, and Tucker (1998).

\section{Empirical Analyses}

\section{Global Impact of Territorial Integrity Norms}

Our first analyses address the global impact of territorial integrity norms. Figure 1 revealed a sharp increase in violent territorial integrity obligations in the middle of the 20th century, followed by a period of relative stability, and a sharp increase in general territorial integrity obligations in the late 20th century. Figure 2 complements this by examining patterns in fatal conflict over territory. Most years have seen between 0-0.4 fatal disputes over territory per nation-state, with a few spikes with higher levels of conflict -- but three of the four highest spikes occurred after violent territorial integrity obligations had stabilized at a high level. The 
rise in general territorial integrity obligations does seem to be accompanied by low levels of territorial conflict, suggesting that these obligations may have been more effective, but more systematic analysis must be undertaken before clear conclusions can be drawn.

[Figure 2 about here]

Table 1 presents the results of a series of negative binomial regression analyses. In each analysis, the alpha parameter is positive and (in all but one case) statistically significant, indicating that a negative binomial model is more appropriate than a Poisson regression, which assumes that the value of alpha is zero. Each model controls for the number of states in the interstate system, which seems likely to increase the amount of conflict as the system has grown. Not surprisingly, this control variable has a positive effect (increasing conflict) in many of the models, although this effect is not always statistically significant.

[Table 1 about here]

Table 1 analyzes three different forms of challenges to the territorial status quo: fatal militarized disputes over territory, violent territorial changes, and peaceful territorial changes. ${ }^{11}$ For each, the strength of the territorial integrity norm is measured by three different approaches: (1) dummy variables indicating the three main phases in the development of the norm as described by Zacher, (2) the average number of total territorial integrity obligations in the international system for each year of observation, and (3) the average number of violent and general territorial integrity obligations for each year. The results vary substantially, indicating that the way the norm is measured can have a major impact on the results.

${ }^{11}$ The number of fatal territorial disputes ranges from zero to seven per year; total disputes over territory (fatal or otherwise) range from zero to sixteen. The number of peaceful territorial changes ranges from zero to twenty, and violent territorial changes range from zero to fourteen. 
We begin with militarized conflict over territory. Each stage in Zacher's characterization of the development of the norm has a statistically significant effect in Model I, indicating that more territorial conflict occurred during each of these eras (controlling for the number of states in the international system) than in the 1816-1918 period before the norm was first encapsulated in written form. The largest substantive effect was for the 1946-1975 period and the smallest was for the 1976-2001 period, which suggests that territorial conflict has been somewhat less likely during the norm internalization phase than during the cascade stage, but fatal territorial conflict is still much more likely in each of these eras than before the norm began to develop. ${ }^{12}$

We obtain similar results when measuring the strength of the norm by explicit treaty obligations. The total treaty obligations measure in Model II has a significant and positive effect $(\mathrm{p}<.01)$, indicating that more fatal territorial conflict occurred in years when there were more territorial integrity treaty obligations in the system. It is only in Model III that we see the first reduction in territorial conflict that can be associated with the territorial integrity norm. In that model, higher average levels of violent territorial integrity obligations are still associated with more fatal territorial conflict $(\mathrm{p}<.05)$. However, higher levels of general territorial integrity obligations are associated with significantly less fatal conflict $(\mathrm{p}<.01)$, suggesting that general obligations to maintain the territorial status quo are much more effective at avoiding serious

\footnotetext{
${ }^{12}$ One reviewer suggested that this might be explained at least partially by the availability of better information about conflicts in recent years, which would mean that the MID data set includes most recent conflicts while missing more conflicts that occurred in earlier years. While we acknowledge this possibility, we have minimized it by focusing on fatal conflicts, which are more likely to be recorded than conflicts that end quickly and bloodlessly. Furthermore, to the extent that this problem exists, it would affect all quantitative research on conflict (particularly research on phenomena that have become more prominent over time, such as democracy).
} 
conflict than are proscriptions of the forceful acquisition of territory (which leave open the ability to seek revision through other means). ${ }^{13}$

Turning to the exchange of territory, the strength of the territorial integrity norm appears to have had less of an impact. None of the historical phases in the development of the norm has seen significant increases or decreases in the frequency with which territory changes hands. The total number of territorial integrity obligations in the system has had no systematic impact on violent territorial changes $(\mathrm{p}<.84)$, although greater levels of such obligations have been associated with fewer peaceful territorial changes $(\mathrm{p}<.06)$. Violent territorial integrity obligations have had little impact on violent changes $(\mathrm{p}<.25)$, although reducing peaceful changes $(\mathrm{p}<.001)$. Finally, general territorial integrity obligations have been associated with significantly less of both violent $(p<.03)$ and peaceful $(p<.001)$ changes. ${ }^{14}$

Together, these results suggest that the territorial integrity norm has had a surprisingly small effect on territorial conflict. The three phases in the development of the norm have all seen more territorial conflict than the period before the norm, and none has seen any reduction in the frequency of territorial changes. Measuring the strength of the norm based on treaty obligations produces similar results, with more obligations being associated with more armed conflict over territory but less peaceful territorial changes. Finally, violent territorial integrity obligations have been associated with more armed conflict but less peaceful changes, while only general obligations have been associated with less armed conflict, violent changes, and peaceful changes. Of course, it is possible that these results can be explained by aggregation problems. Just

${ }^{13}$ Similar results are produced by analyses of all territorial disputes as well as those with at least 100 fatalities. Several variables that have positive associations with conflict fail to achieve statistical significance, but in each case the norm still fails to reduce conflict over territory. 
because the average state has more treaty obligations and the overall international system has more territorial conflict does not indicate that the states with the treaty obligations are those involved in the conflict. We thus turn to a dyadic analysis.

[Table 2 about here]

\section{Dyadic Impact of Territorial Integrity Norms}

Table 2 presents an analysis of the impact of territorial integrity norms on the territorial conflict behavior of individual dyad. Logistic regression is used, modeling the likelihood that a fatal militarized dispute over territorial issues will begin during a particular dyad-year. Five models are presented, the first three of which correspond to the three models from Table 1 except for the addition of dyadic control variables. This table also adds two further models, replacing the global average treaty obligations with the number of shared territorial integrity obligations between the members of the dyad during each year of observation.

The results of the first three models in Table 2 are consistent with the global analyses presented in Table 1. Fatal territorial conflict is significantly more likely in each of the three phases of the norm's development than in the referent category of all years before 1919, when there are more territorial integrity obligations for the average state in the international system, and when there are more violent territorial integrity obligations; conflict is also significantly less likely when the average state has more general territorial integrity obligations. In short, considering dyadic-level control variables does not change the original results.

${ }^{14}$ If violent and peaceful territorial changes are combined, the only significant effects involve a reduction in territorial changes with higher levels of either violent $(\mathrm{p}<.001)$ or general $(\mathrm{p}<$ .001) territorial integrity obligations. 
The final two models in this table suggest an important caveat. While the average level of territorial integrity obligations in the system has a systematic impact on conflict, states' interactions do not appear to be influenced in any systematic sense by their shared treaty commitments. Neither the total territorial integrity obligations shared by two state $(p<.81)$ nor their disaggregated violent $(p<.12)$ and general obligations $(p<.24)$ has a systematic effect on the likelihood of fatal territorial conflict. ${ }^{15}$ The effect of the norm on a state's interaction with a potential adversary, then, appears to depend more on pressure by outside states than on shared treaty commitments. This is consistent with parts of Zacher's argument, which emphasized the global normative context rather than individual states' treaty obligations.

This is not the end of the story, though; it is important to consider several possible limitations of these analyses. Different treaties may have had different effects, in which case the impact of shared treaty obligations on conflict behavior in Table 2 may have been weakened by including treaties that had opposite effects. Territorial integrity treaties may also reflect the context in which the treaties are signed, rather than having any separate influence on states' behavior. The remaining analyses address these possibilities.

\section{Context and Territorial Integrity Obligations}

A potentially important challenge to the idea of a territorial integrity norm involves the context in which territorial integrity treaties are signed. If the norm is to have an independent effect, it must be able to influence states' behavior, leading them to do something that they otherwise would not have done or to avoid doing something that they otherwise would have done. A norm of territorial integrity would thus only affect states' behavior if it led them to

\footnotetext{
${ }^{15}$ Generally similar results emerge with alternative measures of conflict.
} 
avoid conflict that they otherwise would have undertaken. If states that would have had no interest in territorial conflict sign a territorial integrity treaty and subsequently do not engage in territorial conflict, it would be misleading to characterize the norm as successful.

It may be that states are only willing to accept territorial integrity obligations when territorial borders are already accepted by all relevant actors. In such cases, the apparent obligation only reinforces what already exists, rather than restricting states' abilities to pursue their interests. The treaty obligations would appear to be associated with peace, but only because the states that are willing to accept such obligations are unlikely to become involved in territorial conflict with or without the treaty. Alternatively, it may be that territorial integrity treaties represent a desperate measure that is only attempted in the most dangerous situations, where states attempt to create institutions to manage grave threats to regional stability. In such cases, territorial integrity obligations might appear to have a positive relationship with conflict, which could be interpreted as showing that signing territorial integrity treaties "causes" an increase in territorial conflict, when the territorial threat spawned both the treaties and the conflicts.

[Tables 3 and 4 about here]

We consider this possibility in Tables 3 and 4. A separate analysis is run for each treaty, using the set of all dyads composed of two states that eventually accepted the treaty. Each dyad is included from the first year that both states in the dyad were members of the COW international system to the end of the study (2001) or the last year when both states accepted the treaty; we do not have any systematic expectation for the aftermath of a treaty's termination or a state's withdrawal from a treaty. The key variables in these analyses are a dummy variable indicating the last decade before the treaty took effect for the dyad, which will be used to 
investigate the effect of changing relations before the treaty, and a dummy variable indicating all years when the treaty was in effect for the dyad.

Table 3 presents the results for two of the 22 treaties for which analyses were run; the results for all 22 treaties are summarized in Table 4 . The control variables generally produced the same effects as in Table 2. For the League of Nations, a violent territorial integrity obligation, fatal territorial conflict was significantly more likely in the last decade before the treaty took effect $(\mathrm{p}<.01)$, as well as in years when the treaty was in effect for each dyad $(\mathrm{p}<$ .001). For the Non-Aligned Movement, a general territorial integrity obligation, fatal territorial conflict was significantly less likely in the decade before the treaty took effect $(\mathrm{p}<.02)$, but there has been no systematic effect on territorial conflict while the treaty was in effect $(\mathrm{p}<.44)$.

Considering the summary of results presented in Table 4, several findings become apparent. First, most of these territorial integrity obligations began -- or took effect -- in times when territorial conflict had already been reduced or ended. Four of the 22 treaties followed decades where fatal territorial conflict was already significantly less likely than it had been in earlier years, and another ten followed decades where no such conflict occurred between any eventual members. Only two -- the League of Nations and the Andean Community -- came into force following decades where territorial conflict among the members was significantly more likely than it had been in earlier years. The remaining six treaties followed decades where at least one fatal territorial dispute occurred, but the likelihood of such conflict was not systematically different from earlier years. Fourteen of 22 treaties thus followed decades with either no territorial conflict or a significantly reduced likelihood of such conflict, and only two came out of contexts where conflict was more likely than it had been in earlier years. This suggests a selection effect in the choice to accept territorial integrity obligations, which generally 
are not attempted in contexts with substantial conflict. The acceptance of these obligations lies beyond the scope of the present paper, but it appears to be an important topic for future research.

The other important result is the general lack of systematic effects. Only two of the 22 treaties have had a statistically significant impact on conflict behavior while they were in force: fatal territorial conflict was more likely while the League of Nations was in effect $(p<.001)$, and less likely while SAARC has been in effect $(\mathrm{p}<.001)$. Six other treaties have not witnessed a single fatal territorial conflict while in effect, but only three of these were in effect for at least a decade before the end of the study. Rather than the results in Table 2 being weakened by opposite effects canceling each other out, it appears that the reason for the lack of effect of shared treaty obligations is the general lack of effect of the individual treaties.

\section{Discussion}

Taken together, this study's analyses suggest a clearer picture of the impact of territorial integrity norms. First, there have been two distinct territorial integrity norms, one that proscribes the acquisition of territory by force and one that seeks to preserve territorial integrity more generally. Both norms are becoming increasingly widespread, but their effects are quite different. Violent territorial integrity obligations -- which have been far more common, at least until the late twentieth century -- have had little systematic impact, and indeed seem to be associated with greater territorial conflict in some analyses. General obligations, while much less common than violent obligations throughout most of the period of this study, have been associated with a significant decrease in numerous measures of territorial conflict.

This difference in effects suggests that the distinction is important. The impact of general territorial obligations is consistent with Zacher's expectations, and indicates that these efforts to 
maintain the absolute territorial integrity of member states have been relatively successful -reducing both armed conflict over territory and territorial changes. The impact of violent obligations, though, suggests that specific treaty obligations make an important difference. Stronger global support for a norm opposing the violent transfer of territory does not appear to reduce territorial conflict, and is actually associated with more conflict in both the aggregated and dyadic analyses. We do not conclude that such obligations cause territorial conflict, but they do not reduce conflict, and several followup analyses shed additional light on this finding.

Dyadic investigation of the territorial integrity norm (measured three different ways) and specific pairs of potential adversaries suggests that the greatest impact of the norm stems from pressure by other states in the international system that have accepted the norm, rather than from any direct effect of the norm on interactions between states that share obligations under the same treaty. Territorial integrity treaty obligations shared by two potential adversaries -- whether these involve violent, general, or total obligations -- have not had a systematic impact on territorial conflict. In contrast, the average global level of territorial integrity obligations strongly predicts conflict behavior both in aggregated analyses of territorial conflict across the entire interstate system and in dyadic analysis of territorial conflict between pairs of potential adversaries. To us, this indicates that greater global support for general territorial integrity has an important influence on the behavior of individual states or dyads, even when they themselves have not accepted the norm's obligations in formal treaties. States that have accepted the norm, particularly more powerful states that are able to intervene diplomatically or militarily beyond their immediate borders, are likely to attempt to convince others to follow the norm, as the major Western powers did in Zacher's (2001) narrative of the strengthening norm. 
As for the impact of violent territorial integrity obligations at the global level -- which are associated with significant increases in conflict in both aggregated and dyadic analyses -- this analysis suggests further confirmation that such obligations are not directly causing territorial conflict, because states sharing more such obligations do not experience significantly more or less territorial conflict than those share fewer or no such obligations. We feel that a more plausible interpretation is that violent territorial integrity obligations seem to have been much more likely than general obligations to be inserted into large treaties that contain numerous other (unrelated) provisions. We have not made institutional design a central element in our analyses beyond the type of territorial integrity obligation that a given treaty contains, but the three treaties with violent territorial integrity obligations that have had the most members -- the League of Nations covenant, UN charter, and OAS charter -- all involve general-purpose organizations with many further obligations that are unrelated to territorial integrity. The insertion of territorial integrity provisions into such treaties may be an important indication of growing international support for this norm, but the decision to sign such treaties may offer less evidence of support for the norm than signing a treaty in which this obligation is more central. If much of the evidence for the existence of a violent territorial integrity norm comes from these multipurpose treaties, it is plausible that many states would sign such treaties for other reasons, but devote little effort to preventing or defeating territorial challenges -- which could produce a positive relationship between the violent territorial integrity norm and territorial conflict.

Finally, few individual treaties -- regardless of the type of obligation that is involved -have had a significant effect on territorial conflict between members. 14 of 22 treaties were created in periods of reduced or no territorial conflict among the eventual signatories, though, and only two followed a decade of significantly higher than usual territorial conflict. This 
suggests an important selection effect, where such treaties are most likely to be created in contexts where territorial conflict has already been reduced. The most important effect of such treaties, then, is the continuation of the already reduced levels of territorial conflict. Notably, most of the successes seem to involve treaties with general territorial integrity obligations; this is consistent with the earlier observation that general obligations have been more successful than violent at reducing territorial conflict.

One important contribution of this study has been the systematic evaluation of an important norm. While the increasing frequency of treaties with explicit territorial integrity provisions has been interpreted as indicating growing acceptance of a territorial integrity norm, the impact of this norm has never been subjected to rigorous empirical analysis. This study's analyses reveal that territorial integrity norms have not been nearly as effective at avoiding challenges to the territorial status quo or reducing armed conflict as some have argued. While general territorial integrity obligations appear to have been associated with a reduction in territorial conflict, violent territorial integrity obligations -- which have historically been much more frequent than general obligations -- have had the opposite effect. ${ }^{16}$

This is not the final word on the impact of this norm, though. While both this paper and Zacher's study have examined the norm's effect on armed conflict over territory, it may also affect other dimensions of behavior. One of the goals of general territorial integrity obligations such as the Locarno Pact or OAU Charter has been to prevent the emergence of any challenges to the territorial status quo (militarized or otherwise), so such obligations might be expected to

${ }^{16}$ It could be suggested that these results reflect states' propensity to comply with treaty commitments rather than to behave in accordance with international norms. While this is certainly possible, we believe that it is not a major challenge to our results, because we have measured the strength of the norm in three different ways -- only one of which, shared treaty obligations between two states, directly involves treaty commitments. 
prevent the onset of new territorial claims; violent territorial integrity obligations might not produce a similar expectation. By promoting support for the territorial status quo, both types of territorial integrity obligation might also be expected to increase the peaceful management or ending of territorial claims that were already underway. Future research should investigate these and other possible effects of the territorial integrity norm.

It would also be desirable for future work to examine the impact of the territorial integrity norm in specific regions with territorial problems. For example, after independence from Spain, the Latin American states are widely believed to have avoided territorial conflict through the legal principle of uti possidetis, which proclaimed the acceptance of colonial borders as the borders between independent states in order to minimize fratricidal conflicts over territory. While uti possidetis is typically associated with the Latin American experience, it has also been applied elsewhere. most notably in the OAU's 1963 charter and 1964 Cairo Declaration. While the present study has focused on global patterns of territorial conflict over the past two centuries, future research should investigate the Latin American and African experiences in more detail. Scholars such as Kacowicz (1994, 2005), Zacher (2001), and Castellino and Allen (2003) suggest that uti possidetis and related doctrines and institutions helped to stabilize what otherwise would have been much deadlier relations between the newly independent states of these regions, and Kornprobst (2002) makes a similar argument about West Africa. Yet Hill (1945), Prescott (1987), and Lalonde (2002) suggest that uti possidetis was unable to solve many of the most difficult territorial problems in these regions and in fact may have created more. Similarly, Kornprobst (2002) notes that the territorial integrity norm in the Horn of Africa was secondary to the primary norm of decolonization, with the result that border disputes not only developed but endured and escalated to war. Further research should investigate which of these 
characterizations is most accurate and under which conditions, which would greatly increase our understanding of the sources and management of territorial conflict in the modern era. 


\section{References}

Beck, Nathaniel, Jonathan N. Katz, and Richard Tucker. (1998). "Taking Time Seriously: Time-series-cross-section analysis with a binary dependent variable." American Journal of Political Science 42 (4): 1260-1288.

Bell, P. M. H. (1997). The Origins of the Second World War in Europe. New York: Longman.

Bowker, Mike, and Phil Williams. (1985). "Helsinki and West European Security."

International Affairs 61, 4 (Autumn): 607-618.

Castellino, Joshua A., and Steve Allen. (2003). Title to Territory in International Law: A

Temporal Analysis. Burlington, VT: Ashgate.

Chime, Samuel. (1969). "The Organization of African Unity and African Boundaries." In Carl Gösta Widstrand, ed., African Boundary Problems. Uppsala, Sweden: Scandinavian Institute of African Studies, pp. 63-78.

Dixon, William J. (1993). "Democracy and the Management of International Conflict." Journal of Conflict Resolution 37: 42-68.

Finnemore, Martha and Kathryn Sikkink. (1998). "International Norm Dynamics and Political Change." International Organization 52 (4): 887-917.

Florini, Ann. (1996). "The Evolution of International Norms." International Studies Quarterly 40 (4): 363-389.

Ghosn, Faten, Glenn Palmer, and Stuart A. Bremer. (2004). "The MID3 Data Set, 1993-2001: Procedures, Coding Rules, and Description." Conflict Management and Peace Science 21 (2):133-154.

Gilbert, Felix. (1984). The End of the European Era, 1890 to the Present, 3rd edition. New York: W. W. Norton and Company.

Goertz, Gary, and Paul F. Diehl. (1992). "Toward a Theory of International Norms: Some Conceptual and Measurement Issues." Journal of Conflict Resolution 36, 4 (December): 634664.

Hensel, Paul R. (2001). "Contentious Issues and World Politics: The Management of Territorial Claims in the Americas, 1816-1992." International Studies Quarterly 45 (1):81-109.

Herbst, Jeffrey. (1989). "The Creation and Maintenance of National Boundaries in Africa." International Organization 43,4 (Autumn): 673-692. 
Hill, Norman. (1945). Claims to Territory in International Law and Relations. London, UK: Oxford University Press.

Huth, Paul K., and Todd Allee. (2002). The Democratic Peace and Territorial Conflict in the Twentieth Century. Cambridge, UK: Cambridge University Press.

Kacowicz, Arie M. (1994). Peaceful Territorial Change. Columbia, SC: University of South Carolina Press.

Kacowicz, Arie M. (2005). The Impact of Norms in International Society: The Latin American Experience, 1881-2001. Notre Dame, IN: University of Notre Dame Press.

Kegley, Charles W. , Jr., and Gregory A. Raymond. (1990). When Trust Breaks Down : Alliance Norms and World Politics. Columbia, SC: University of South Carolina Press.

Kornprobst, Markus. (2002). "The Management of Border Disputes in African Regional SubSystems: Comparing West Africa and the Horn of Africa." Journal of Modern African Studies 40, 3 (September): 369-393.

Krasner, Stephen D. (1982). "Structural Causes and Regime Consequences: Regimes as Intervening Variables." International Organization 36 (2): 185-205.

Lalonde, Suzanne. (2002) Determining Boundaries in a Conflicted World: The Role of Uti Possidetis. Montreal: McGill-Queen's University Press.

Malanczuk, Peter. (1997). Akehurst's Modern Introduction to International Law, 7th revised edition. New York, NY: Routledge.

Mitchell, Sara McLaughlin. (2002). "A Kantian System? Democracy and Third Party Conflict Resolution." American Journal of Political Science, 46(4): 749-759.

Prescott, J. R. V. (1987). Political Frontiers and Boundaries. Boston, Mass.: Unwin Hyman.

Ratner, Steven R. (1996). "Drawing a Better Line: Uti Possidetis and the Borders of New States." American Journal of International Law 90 (4):590-624.

Russell, Harold S. (1976). "The Helsinski Declaration: Brobdingnag or Lilliput?" American Journal of International Law 70, 2 (April): 242-272.

Singer, J. David. (1988). "Reconstructing the Correlates of War Dataset on Material Capabilities of States, 1816-1985." International Interactions 14 (2):115-32.

Touval, Saadia. (1972). The Boundary Politics of Independent Africa. Cambridge: Harvard University Press.

Zacher, Mark W. (2001). "The Territorial Integrity Norm: International Boundaries and the Use of Force." International Organization 55 (2):215-250. 
Figure 1: Territorial Integrity Treaty Obligations

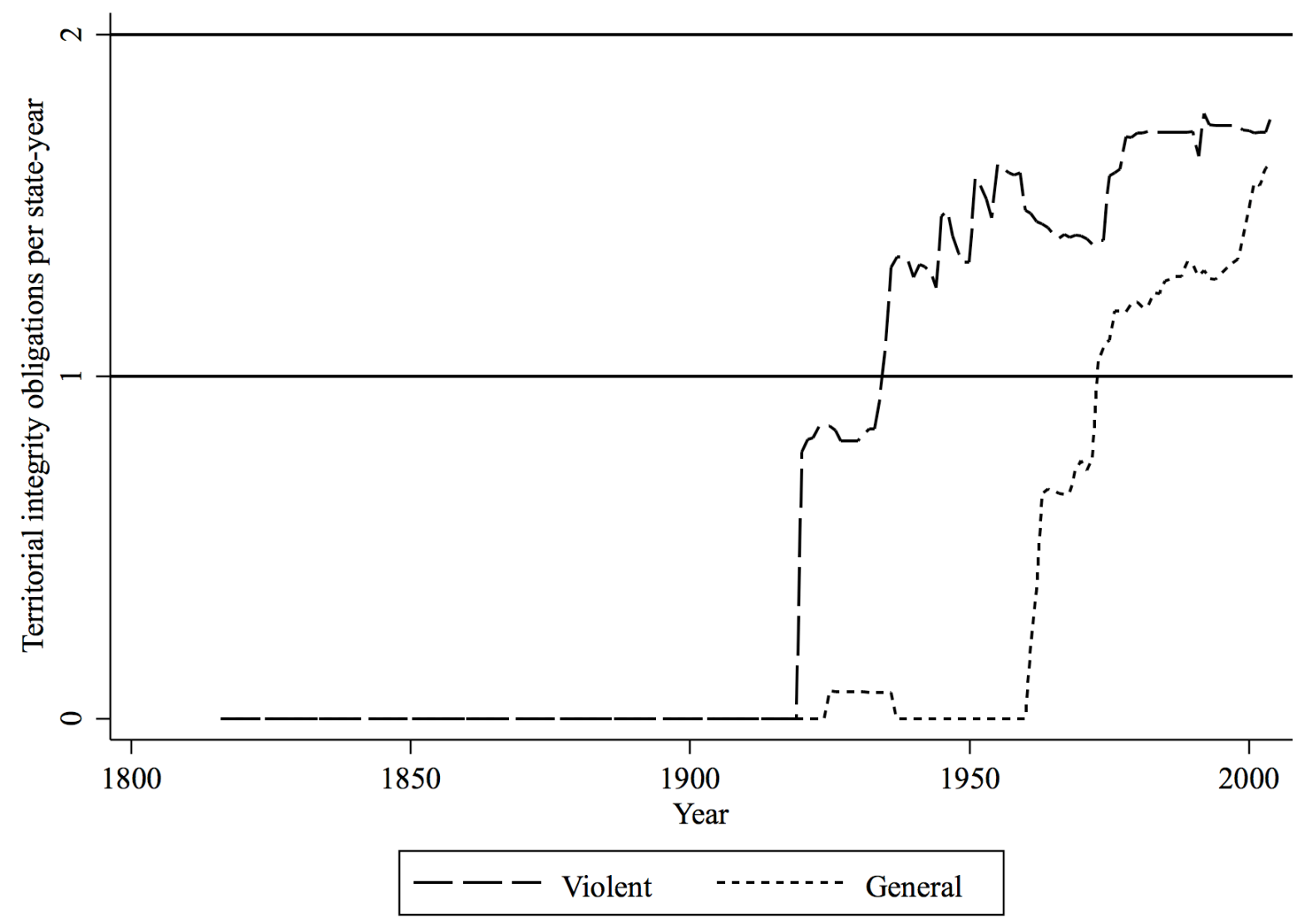


Figure 2: Fatal Militarized Disputes over Territorial Issues

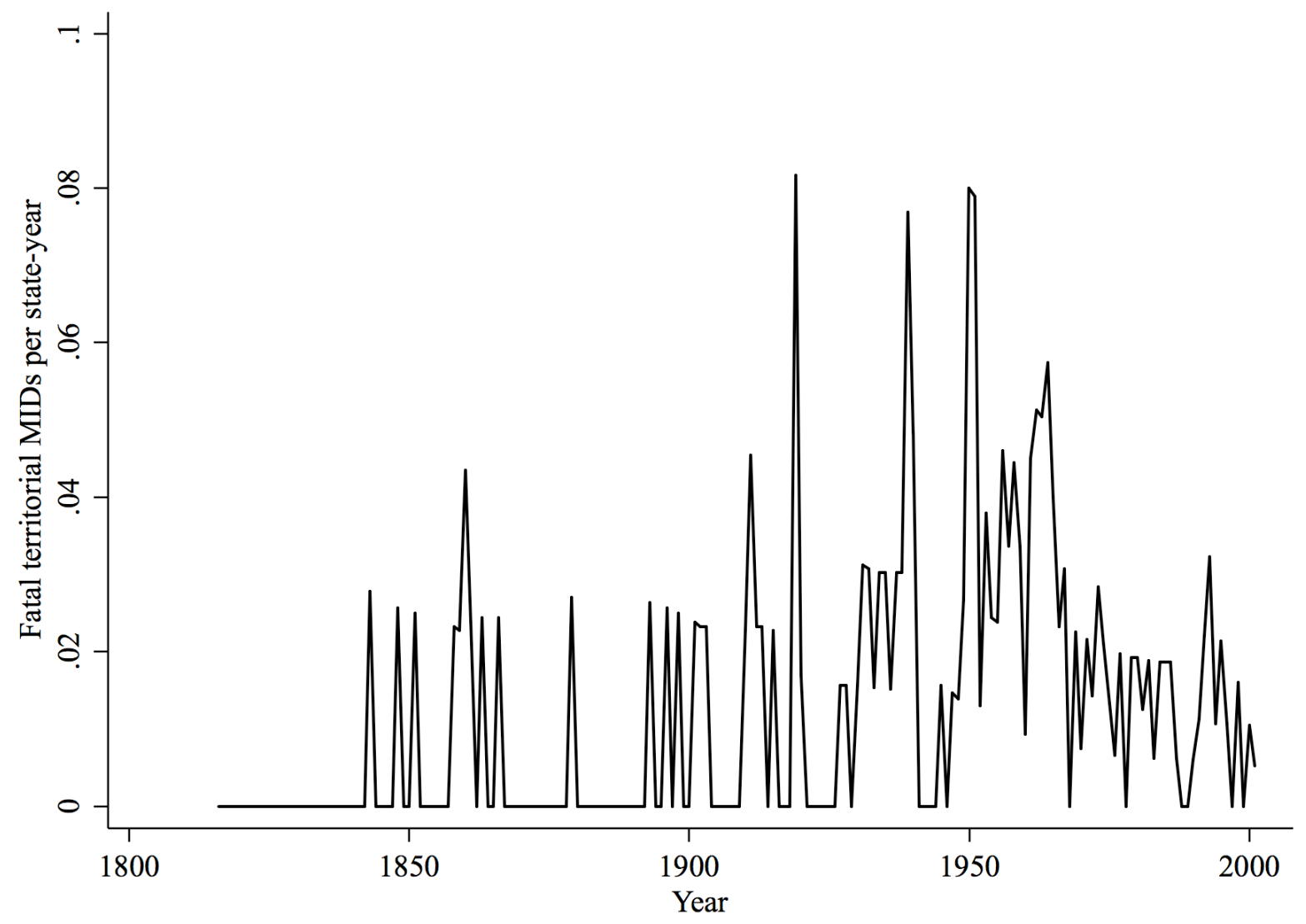


Table 1: Aggregated Analysis of Territorial Integrity Obligations and Territorial Conflict

\section{A. Fatal Militarized Disputes over Territorial Issues}

\begin{tabular}{lllc} 
Variable & Model I & Model II & Model III \\
\hline 1919-1945 & $1.49(0.30)^{* * *}$ & --- & --- \\
1946-1975 & $2.21(0.38)^{* * *}$ & --- & --- \\
1976-2001 & $1.42(0.60)^{* *}$ & --- & --- \\
Total TI Obligations & --- & $1.24(0.33)^{* * *}$ & --- \\
Violent TI Obligations & --- & --- & $0.62(0.31)^{* *}$ \\
General TI Obligations & --- & --- & $-2.61(0.67)^{* * *}$ \\
States in system & $0.01(0.004)$ & $-0.01(0.01)$ & $0.03(0.01)^{* * *}$ \\
Constant & $-1.72(0.26)^{* * *}$ & $-0.61(0.26)^{* * *}$ & $-2.57(0.40)^{* * *}$ \\
& & & \\
& $\mathrm{~N}: 186$ & $\mathrm{~N}: 186$ & $\mathrm{~N}: 186$ \\
& $\mathrm{LL}:-204.73$ & $\mathrm{LL}:-228.97$ & $\mathrm{LL}:-208.61$ \\
& $\mathrm{X}=122.02 * * *$ & $\mathrm{X}=73.54 * * *$ & $\mathrm{X}^{2}=114.27 * *$ \\
& $\alpha: 0.08$ & $\alpha: 0.49 * * *$ & $\alpha: 0.18^{* *}$
\end{tabular}

\section{B. Violent Territorial Changes}

\begin{tabular}{lccc} 
Variable & Model I & Model II & Model III \\
\hline $1919-1945$ & $0.42(0.36)$ & --- & --- \\
$1946-1975$ & $0.27(0.60)$ & --- & --- \\
$1976-2000$ & $-0.72(1.18)$ & --- & --- \\
Total TI Obligations & --- & $-0.07(0.36)$ & $-0.47(0.41)$ \\
Violent TI Obligations & --- & --- & $-2.53(1.17)^{* *}$ \\
General TI Obligations & --- & --- & $0.02(0.01)$ \\
States in system & $-0.01(0.01)$ & $-0.01(0.01)$ & $-0.40(0.58)$ \\
Constant & $0.50(0.34)$ & $0.67(0.33)^{* *}$ & \\
& & & $\mathrm{~N}: 185$ \\
& $\mathrm{~N}: 185$ & $\mathrm{~N}: 185$ & $\mathrm{LL}:-271.15$ \\
& $\mathrm{LL}:-271.13$ & $\mathrm{LL}:-273.63$ & $\mathrm{X}^{2}=14.33^{* * *}$ \\
& $\mathrm{X}^{2}=14.36^{* * *}$ & $\mathrm{X}^{2}=9.38^{* * *}$ & $\alpha: 1.42^{* * *}$
\end{tabular}




\section{Peaceful Territorial Changes}

\begin{tabular}{|c|c|c|c|}
\hline Variable & Model I & Model II & Model III \\
\hline 1919-1945 & $-0.12(0.22)$ & --- & --- \\
\hline $1946-1975$ & $0.11(0.37)$ & --- & --- \\
\hline $1976-2000$ & $-0.95(0.66)$ & --- & --- \\
\hline Total TI Obligations & --- & $-0.47(0.24)^{*}$ & --- \\
\hline Violent TI Obligations & --- & --- & $-0.90(0.24)^{* *}$ \\
\hline General TI Obligations & --- & --- & $-3.00(0.54) * * *$ \\
\hline States in system & $0.01(0.004)$ & $0.01(0.01) * *$ & $0.04(0.01)^{* * *}$ \\
\hline Constant & $-1.72(0.26)^{* * *}$ & $0.69(0.21)^{* * *}$ & $-0.44(0.29)$ \\
\hline & $\begin{array}{l}N: 185 \\
\text { LL: }-412.53 \\
\mathrm{X}^{2}=15.28^{* * *} \\
\alpha: 0.43^{* * *}\end{array}$ & $\begin{array}{l}\mathrm{N}: 185 \\
\mathrm{LL}:-417.05 \\
\mathrm{X}^{2}=6.23 * * \\
\alpha: 0.47 * * *\end{array}$ & $\begin{array}{l}\mathrm{N}: 185 \\
\text { LL: }-403.89 \\
\mathrm{X}^{2}=32.56^{* * *} \\
\alpha: 0.35^{* * *}\end{array}$ \\
\hline
\end{tabular}


Table 2: Dyadic Analysis of Territorial Integrity Obligations and Fatal Territorial Conflict

\begin{tabular}{|c|c|c|c|}
\hline Variable & Model I & Model II & Model III \\
\hline $1919-1945$ & $1.75(0.23) * * *$ & --- & --- \\
\hline 1946-1975 & $1.25(0.26)^{* * *}$ & --- & --- \\
\hline 1976-2001 & $0.84(0.23)^{* * *}$ & --- & --- \\
\hline Global Obligations-Total & --- & $0.12(0.05)^{* *}$ & --- \\
\hline Global Obligations-Violent & --- & --- & $1.19(0.15)^{* * *}$ \\
\hline Global Obligations-General & --- & -- & $-1.07(0.16)^{* * *}$ \\
\hline Contiguous by land & $3.71(0.29) * * *$ & $3.75(0.29)^{* * *}$ & $3.68(0.29)^{* * *}$ \\
\hline Major power in dyad & $1.30(0.28) * * *$ & $1.18(0.29)^{* * *}$ & $1.30(0.29)^{* * *}$ \\
\hline Joint democracy & $-0.80(0.34)^{* *}$ & $-0.72(0.33)^{* *}$ & $-0.78(0.34)^{* *}$ \\
\hline Capability imbalance & $-2.52(0.58) * * *$ & $-2.39(0.55) * * *$ & $-2.53(0.59)^{* * *}$ \\
\hline Peace years & $-0.31(0.04)^{* * *}$ & $-0.30(0.04)^{* * *}$ & $-0.27(0.04) * * *$ \\
\hline Spline 1 & $-0.00(0.00)^{* * *}$ & $-0.00(0.00)^{* * *}$ & $-0.00(0.00) * * *$ \\
\hline Spline 2 & $0.00(0.00)^{* * *}$ & $0.00(0.00)^{* * *}$ & $0.00(0.00)^{* * *}$ \\
\hline Spline 3 & $0.00(0.00)$ & $0.00(0.00)$ & $0.00(0.00)$ \\
\hline \multirow[t]{2}{*}{ Constant } & $-5.98(0.47)^{* * *}$ & $-5.25(0.49) * * *$ & - $5.94(0.49)^{* * *}$ \\
\hline & $\begin{array}{l}\mathrm{N}: 675,081 \\
\mathrm{LL}:-2185.23 \\
\mathrm{X}^{2}: 1901.65^{* * *}\end{array}$ & $\begin{array}{l}\mathrm{N}: 675,081 \\
\text { LL: }-2231.00 \\
\mathrm{X}^{2}: 1682.03^{* * *}\end{array}$ & $\begin{array}{l}\mathrm{N}: 675,081 \\
\mathrm{LL}:-2175.25 \\
\mathrm{X}^{2}: 1792.34^{* * *}\end{array}$ \\
\hline$\underline{\text { Variable }}$ & Model IV & Model V & \\
\hline Shared Obligations-Total & $-0.02(0.07)$ & --- & \\
\hline Shared Obligations-Violent & --- & $-0.24(0.15)$ & \\
\hline Shared Obligations-General & ---- & $0.18(0.15)$ & \\
\hline Contiguous by land & $3.68(0.29) * * *$ & $3.63(0.31)^{* * *}$ & \\
\hline Major power in dyad & $1.05(0.29)^{* * *}$ & $1.03(0.29)^{* * *}$ & \\
\hline Joint democracy & $-0.66(0.33) * *$ & $-0.57(0.31)^{*}$ & \\
\hline Capability imbalance & $-2.35(0.56)^{* * *}$ & $-2.30(0.57)^{* * *}$ & \\
\hline Peace years & $-0.30(0.04)^{* * *}$ & $-0.31(0.04)^{* * *}$ & \\
\hline Spline 1 & $-0.00(0.00)^{* * *}$ & $-0.00(0.00)^{* * *}$ & \\
\hline Spline 2 & $0.00(0.00)^{* * *}$ & $0.00(0.00)^{* * *}$ & \\
\hline Spline 3 & $0.00(0.00)$ & $0.00(0.00)$ & \\
\hline \multirow[t]{4}{*}{ Constant } & $-5.00(0.49)^{* * *}$ & $-4.92(0.49) * * *$ & \\
\hline & $\mathrm{N}: 675,081$ & $\mathrm{~N}: 675,081$ & \\
\hline & LL: -2233.34 & LL: -2229.34 & \\
\hline & $\mathrm{X}^{2}: 1610.28^{* * *}$ & $\mathrm{X}^{2}: 1638.65^{* * *}$ & \\
\hline
\end{tabular}


Table 3: Fatal Territorial Conflict before and after Selected Territorial Integrity Treaties

\begin{tabular}{lcc} 
Variable & League of Nations & Non-Aligned Movement \\
\hline Last decade before treaty & $1.21(0.39)^{* * *}$ & $-0.94(0.40)^{* *}$ \\
Treaty in effect & $1.78(0.35)^{* * *}$ & $-0.27(0.35)$ \\
Contiguous by land & $2.14(0.35)^{* * *}$ & $4.95(0.39)^{* * *}$ \\
Major power in dyad & $1.99(0.48)^{* * *}$ & --- \\
Joint democracy & $-1.75(0.57)^{* * *}$ & $0.26(0.46)$ \\
Capability imbalance & $-2.25(0.90)^{* *}$ & $-0.21(0.97)$ \\
Peace years & $-0.33(0.06)^{* * *}$ & $-0.28(0.08)^{* * *}$ \\
Spline 1 & $-0.00(0.00)^{* * *}$ & $-0.00(0.00)^{* *}$ \\
Spline 2 & $0.00(0.00)^{* * *}$ & $0.00(0.00)$ \\
Spline 3 & $-0.00(0.00)^{* * *}$ & $0.00(0.00)$ \\
Constant & $-5.77(0.78)^{* * *}$ & $-7.20(0.68)^{* * *}$ \\
& & \\
& $\mathrm{~N}: 86,483$ & $\mathrm{~N}: 241,125$ \\
& LL: -624.90 & LL: -629.64 \\
& $X^{2}: 494.14 * *$ & $X^{2}: 435.39 * * *$
\end{tabular}

Logistic regression analysis; standard errors clustered by dyad. 


\section{Table 4: Coefficients for Impact of Individual Territorial Integrity Obligations}

\begin{tabular}{|c|c|c|}
\hline Treaty/Institution (years in effect) & $\begin{array}{l}\text { Last decade } \\
\text { before treaty: }\end{array}$ & Treaty in effect: \\
\hline \multicolumn{3}{|l|}{ Violent Obligations } \\
\hline League of Nations (1920-46): & $1.21(0.39)^{* * *}$ & $1.78(0.35)^{* * *}$ \\
\hline Saavedra Lamas Pact (1933+): & $0.63(0.50)$ & $0.24(1.03)$ \\
\hline Montevideo Convention (1934+): & $1.12(1.33)$ & Perfect $^{\dagger}$ \\
\hline United Nations $(1945+)$ : & $-0.65(0.33) * *$ & $-0.25(0.21)$ \\
\hline OAS $(1951+)$ : & Perfect $^{\dagger}$ & $-0.14(0.89)$ \\
\hline Helsinki Final Act (1975+): & Perfect $^{\dagger}$ & $-0.13(0.34)$ \\
\hline ECOWAS (1978+): & $-0.39(1.46)$ & $-1.42(1.48)$ \\
\hline SADC (2004+): & Perfect $^{\dagger}$ & --- \\
\hline \multicolumn{3}{|l|}{ General Obligations } \\
\hline Locarno Pact (1925-36): & Perfect $^{\dagger}$ & $-0.04(0.84)$ \\
\hline NAM $(1961+)$ & $-0.94(0.40) * *$ & $-0.27(0.35)$ \\
\hline OAU/AU $(1963+)$ : & Perfect $^{\dagger}$ & $0.75(1.08)$ \\
\hline OIC (1973+): & $-0.31(0.54)$ & $-0.01(0.45)$ \\
\hline ASEAN $(1976+)$ : & $-0.46(1.17)$ & Perfect $^{\dagger}$ \\
\hline SAARC (1985+): & $-1.24(0.34)^{* * *}$ & $-1.81(0.39)^{* * *}$ \\
\hline CAN (1989+): & $1.70(0.50)^{* * *}$ & $0.50(0.31)$ \\
\hline CIS (1991+): & Perfect $^{\dagger}$ & Perfect $^{\dagger}$ \\
\hline CICA (1999+): & $-2.08(0.45)^{* * *}$ & $-0.70(1.14)$ \\
\hline $\operatorname{SEECP}(2000+)$ : & $-0.34(0.68)$ & $-0.60(0.72)$ \\
\hline $\operatorname{ECCAS}(2000+)$ : & Perfect $^{\dagger}$ & Perfect $^{\dagger}$ \\
\hline GUUAM/GUAM (2001+): & Perfect $^{\dagger}$ & Perfect $^{\dagger}$ \\
\hline $\operatorname{SCO}(2001+)$ & Perfect $^{\dagger}$ & Perfect $^{\dagger}$ \\
\hline CSTO $(2003+)$ : & Perfect $^{\dagger}$ & --- \\
\hline
\end{tabular}

$* \mathrm{p} \leq .10, * * \mathrm{p} \leq .05, * * * \mathrm{p} \leq .01$

$\dagger$ The variable perfectly predicts peace -- no fatal territorial conflict began during this time. Logistic regression analysis; standard errors clustered by dyad. 